\title{
2. ON THE TECTONIC HISTORY AND ORIGIN OF THE NORTHEAST GEORGIA RISE ${ }^{1}$
}

\author{
Yngve Kristoffersen ${ }^{2}$ and John LaBrecque ${ }^{3}$
}

\begin{abstract}
Northeast Georgia Rise is located on inferred oceanic crust that is considered Albian in age and to have formed during the separation of Africa and South America. Of the three sites $(698,699$, and 700$)$ drilled on the rise during ODP Leg 114, Site 698 reached basement. Basalt overlying a weathered regolith was recovered at Site 698 and a basaltic substratum at the other sites is inferred from the downhole variation in pore-water chemistry. The provenance of a 2 -m-thick gravel bed containing abundant clasts of continental lithologies displaced into lower Oligocene ooze at Site 699 is an enigma. The age of basement at Site 700 estimated by applying the observed Late Cretaceous sedimentation rate to the unrecovered sediments below the total drilling depth indicates an age comparable to the estimated age of the crust in the adjacent ocean basin. From this we infer that at least part of the Northeast Georgia Rise was formed at a spreading center by excessive volcanism. At Site 698 , later off-axis volcanism contributed to the construction of a western ridge that extended above sea level in pre-Campanian time. At least two episodes of deformation have subsequently modified the topography of the rise. Normal faulting that dissected much of the Northeast Georgia Rise by late Oligocene time is in part coeval with the opening of the Scotia Sea. During the Neogene, the western part of Northeast Georgia Rise experienced uplift of the order of $0.5-1 \mathrm{~km}$, increasing toward South Georgia. Interaction with the advancing South Sandwich Trench and/or the South Georgia block may have induced an extensional regime with movement along low-angle normal faults to form much of the present topography of the southwestern part of the rise.
\end{abstract}

\section{INTRODUCTION}

The Northeast Georgia Rise forms a 400 by $400 \mathrm{~km}$ oceanic plateau centered within the Georgia Basin, west of the Falkland Plateau in the South Atlantic (Fig. 1). The western rise forms a large, north-trending arcuate ridge whereas the eastern rise is a broader, lower relief structure of similar trend (Brenner and LaBrecque, 1988). The western Georgia Basin is considered to be floored by oceanic crust, the age of which is determined from lineations of magnetic anomalies M0 through M10 (LaBrecque and Hayes, 1979). If we extrapolate eastward from the position of these isochrons using South Atlantic poles of opening, we find that the Northeast Georgia Rise may be located on crust of Albian age (Fig. 1). The origin of the rise is uncertain, although it has been suggested to have been the locus of a convergent boundary between the South American plate and a smaller Malvinas plate during the middle to Late Cretaceous (LaBrecque, 1986). In this paper we discuss the tectonic evolution of and possible models for the origin of the Northeast Georgia Rise in light of Ocean Drilling Program (ODP) Leg 114 drilling results and the single-channel seismic data collected over the years in preparation for the drilling campaign.

\section{BASEMENT}

Basement relief on the Northeast Georgia Rise can be divided into two structural elements that form a series of fault blocks: a high-standing western ridge with several local small peaks and a lower eastern ridge, with a gentle saddle area in between (Figs. 1 and 2). North of $52^{\circ} \mathrm{S}$ on the western ridge, we can discern several acoustic-reflection events within base-

\footnotetext{
${ }^{1}$ Ciesielski, P. F., Kristoffersen, Y., et al., 1991. Proc. ODP, Sci. Results, 114: College Station, TX (Ocean Drilling Program).

2 Seismological Observatory, University of Bergen, Allégaten 41, N-5014 Bergen, Norway.

Lamont-Doherty Geological Observatory of Columbia University, Palisades, NY 10964.
}

ment in the single-channel seismic data (Figs. 3 and 4). The dips are westward (apparent dip about $3^{\circ}$ ) from Site 698, and events can be followed down to at least $1.5 \mathrm{~km}$ below the sediment/basement interface at the crest of the ridge (Fig. 4). Basement recovery at Site 698 of $10 \mathrm{~m}$ of holocrystalline basalt overlying $18 \mathrm{~m}$ of extremely weathered basalt regolith implies subaerial exposure of the western ridge (Ciesielski, Kristoffersen, et al., 1988). The low seismic velocity of the regolith generates a large impedance contrast that may explain the acoustic layering within basement at this site as well as other areas on the western ridge. These observations are similar in many ways to the results from the Vøring Plateau at Site 642 of ODP Leg 104, where the acoustic stratification within the basement is associated with basalt flows with intercalated sediments laid down in a subaerial or shallowmarine environment (Eldholm, Thiede, et al., 1987). On the Northeast Georgia Rise, the geochemistry of the volcanic basement recovered from Site 698 shows moderately evolved alkali basalts and hawaiites (M. Perfit, pers. comm., 1988). The age of basement at Site 698 is complicated by a $9.4-\mathrm{m}$ gap in recovery above basement. The oldest sediment recovered is the Campanian nannofossil Broinsonia parca Zone, which occurs at Site 700 within the lower Chron C33N and upper Chron C33R (Ciesielski, Kristoffersen, et al., 1988). Therefore, basement is pre-middle Campanian. The westwarddipping acoustic reflections within the basement suggest that the volcanism on the western ridge of Northeast Georgia Rise should be progressively younger to the west.

Basement was not reached at Sites 699 and 700 on the northeastern slope of Northeast Georgia Rise, but a basaltic substratum was inferred from the pore-water geochemistry. The pore-water chemistry is consistent with a diffusive exchange of seawater $\mathrm{Ca}$ and $\mathrm{Mg}$ through the sediment column driven by low-temperature basalt alteration reactions in the basement (Ciesielski, Kristoffersen, et al., 1988). The oldest sediments recovered from Hole 700B are late Turonian (Premoli Silva, this volume). If we use an estimated age of 89.5 Ma for the base of the hole and apply the Late Cretaceous 


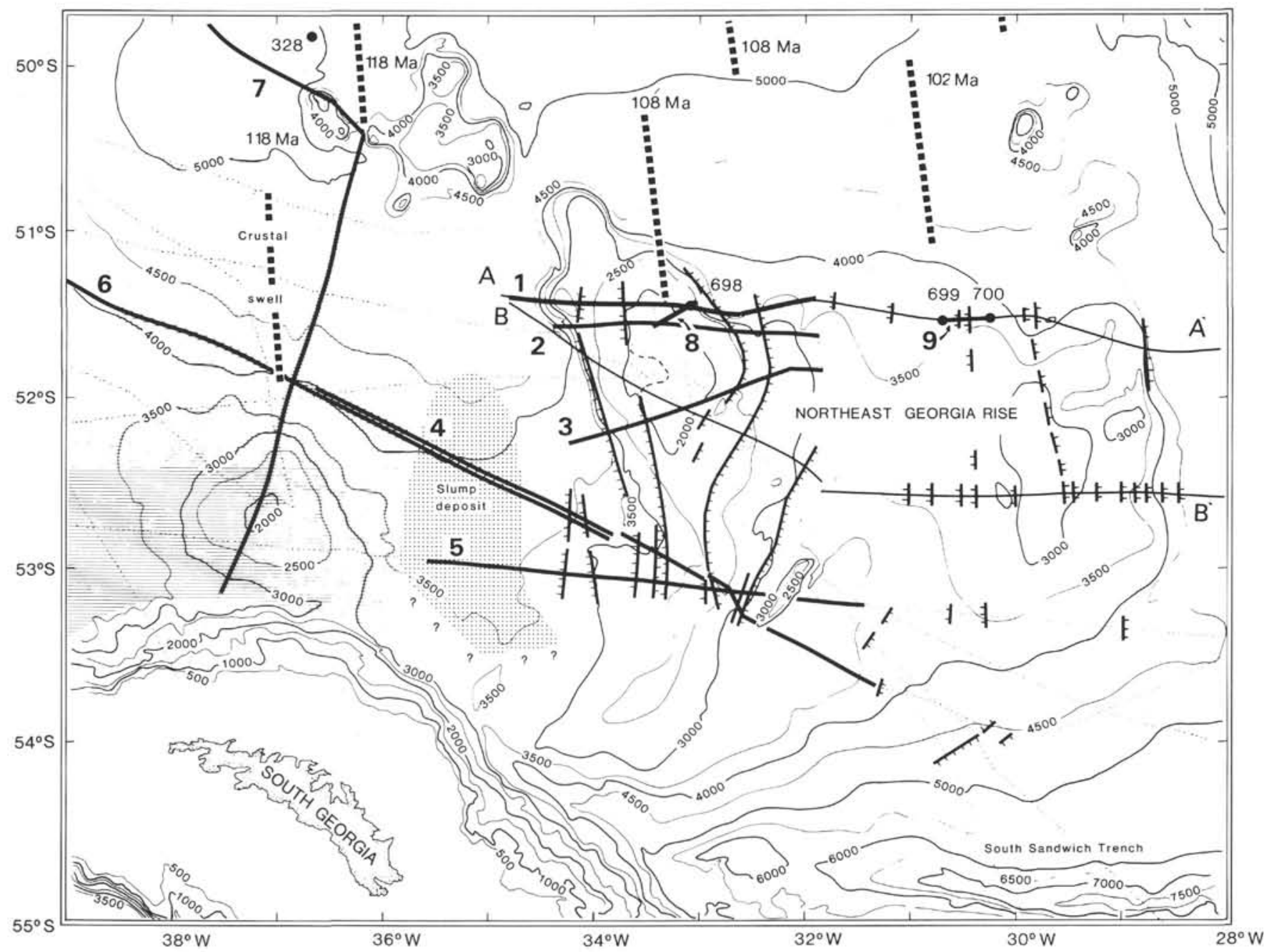

Figure 1. Bathymetry of the Northeast Georgia Rise and environs with locations of DSDP and ODP drill sites, seismic lines AA' and BB' (Fig. 2), and profiles 1-9 (Figs. 3-6 and 10) (after Brenner and LaBrecque, 1988). Dotted lines are other ship tracks with single-channel seismic data. The ruled area outlines the elevated basement north of South Georgia, and a major sediment slump deposit is outlined by the dotted area. The positions of crustal isochrons (dashed lines) and ages refer to the geomagnetic polarity time scale of Kent and Gradstein (1985). The M0 isochron in the Georgia Basin is from LaBrecque (1986) and the other isochrons were predicted by interpolation using M0 and C34 total-opening poles from Rabinowitz and LaBrecque (1979) and Cande et al. (1988). Mapped and inferred fault traces are shown by solid lines, with bars indicating the downthrown side. Inferred fault traces are extended along basement steps in areas on the western ridge where the sediment cover is strongly attenuated.

sedimentation rate at this site $(9 \mathrm{~m} / \mathrm{m}$.y. between 88 and 84 Ma) to an unrecovered 100 -m-thick section above basement, we obtain a minimum age of basement of $100.6 \mathrm{Ma}$ (Fig. 1). This age compares favorably with the extrapolated basement age of $102 \mathrm{Ma}$ (Fig. 1). The occurrence of lower sedimentation rates lower in the section $(4.75 \mathrm{~m} / \mathrm{m} . \mathrm{y}$. between 73 and $84 \mathrm{Ma})$ results in an older estimated age of $110 \mathrm{Ma}$.

The recovery of a 2-m-thick gravel bed embedded in lower Oligocene nannofossil ooze at Site 699 on the northeastern flank of the Northeast Georgia Rise has raised the possibility of a component of continental material within the rise structure (Ciesielski, Kristoffersen, et al., 1988). The gravel appears to be normally graded and poorly sorted, and the dominant lithologies of the subangular to angular $1-5-\mathrm{cm}-$ diameter rock fragments include quartz, schist, basalt, andesite, quartz arenite, granite, oligomict and polymict conglomerates, quartz diorite, and manganese nodules. Emplacement of the gravel bed at Site 699 was most likely by mass flow, as no strong drilling disturbance or poor core recovery occurred above this level. Furthermore, the total volume of ice-rafted material present in the overlying section is far less than the volume of coarse material concentrated in the gravel bed. A mass-flow origin of the gravel bed implies an early Oligocene gravel enrichment event or exposure of gravel upslope as well as an event trigger mechanism. A seismic tie-line between Sites 699 and 700 (Fig. 5) demonstrates that early Oligocene and younger sediments onlap a fault-induced topographic relief and that this part of the rise was indeed affected by tectonic events during the early Oligocene (Ciesielski, Kristoffersen, et al., 1988).

\section{SEDIMENTS}

\section{Sediments on the Northeast Georgia Rise}

The Northeast Georgia Rise is covered by as much as $1 \mathrm{~km}$ of sediments, which locally may exceed $2 \mathrm{~km}$ (assuming an 
A Northeast Georgia Rise

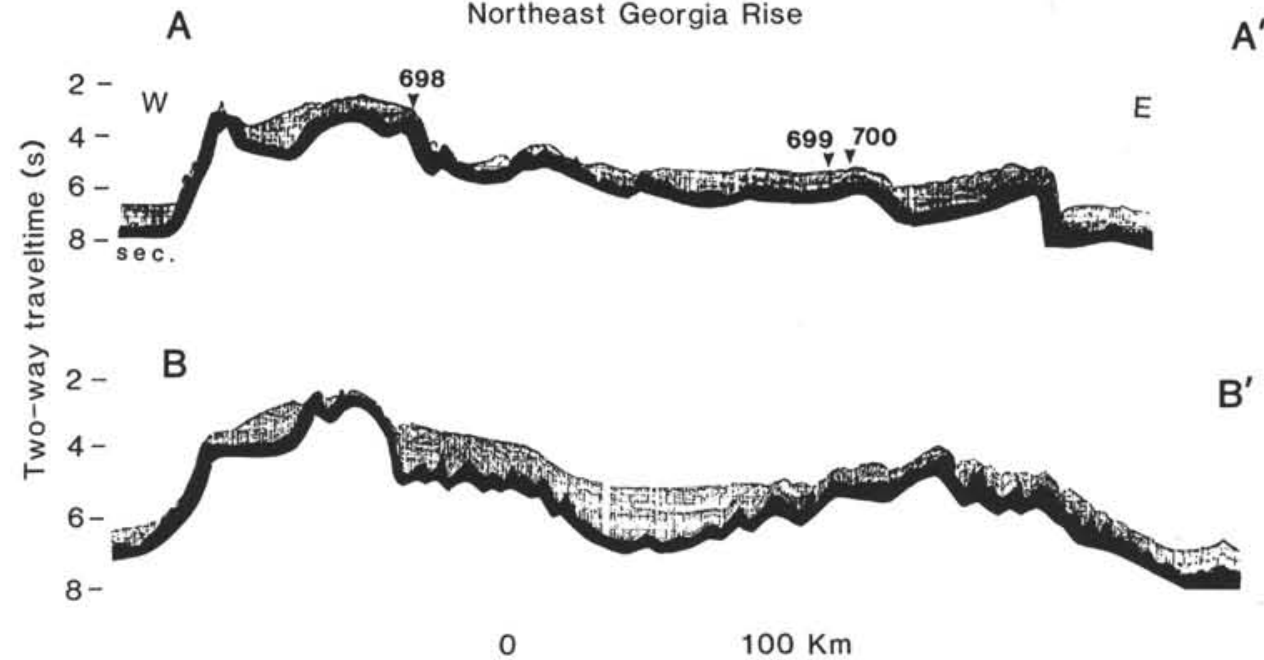

Figure 2. Cross sections of the Northeast Georgia Rise (locations shown in Fig. 1) from seismicreflection profiles, Islas Orcadas Cruise 0775.

average seismic velocity of $2 \mathrm{~km} / \mathrm{s}$ ) in the saddle area between the two basement ridges (Fig. 2). Basement is exposed on the shallowest part of the western ridge and along its perimeter. The lateral continuity of the sedimentary sequence, particularly on the western ridge, is generally disrupted by fault movements and tight folding. The least disturbed area is the northern half of Northeast Georgia Rise (north of $52^{\circ} \mathrm{S}$ ), and the degree of disturbance increases toward South Georgia.

Given the limited resolution of our single-channel seismic data, we can map two major seismic unconformities below the seafloor on the western ridge of the Northeast Georgia Rise (Figs. 3 and 4). Unconformity A is generally conformable with the seafloor. The angular truncations of unconformity B are most clearly expressed in the north part of the ridge. A third unconformity may be present just below unconformity B, but we leave the question open at this point, because of limitations in the quality of the seismic data and uncertainty in navigation for the ties.

The upper sequence NGR-1 reaches a maximum thickness of about $110 \mathrm{~m}$ (assuming a velocity of $1700 \mathrm{~m} / \mathrm{s}$ ) below the

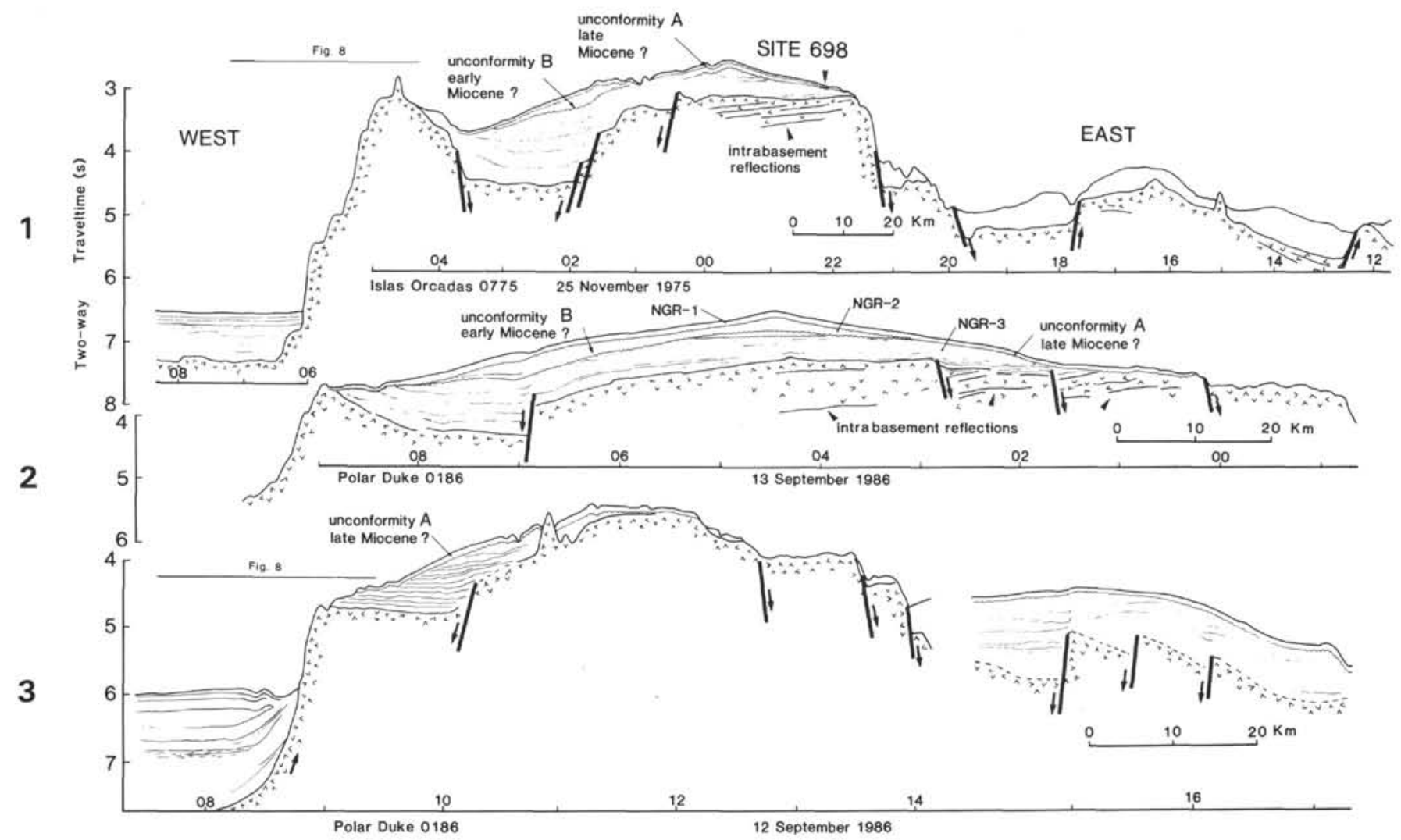

Figure 3. Line drawings of single-channel seismic-reflection profiles across the western ridge of the Northeast Georgia Rise with interpreted unconformities A and B, seismic sequences NGR-1-NGR-3, and basement faults. Profile locations 1, 2, and 3 are shown in Figure 1. 


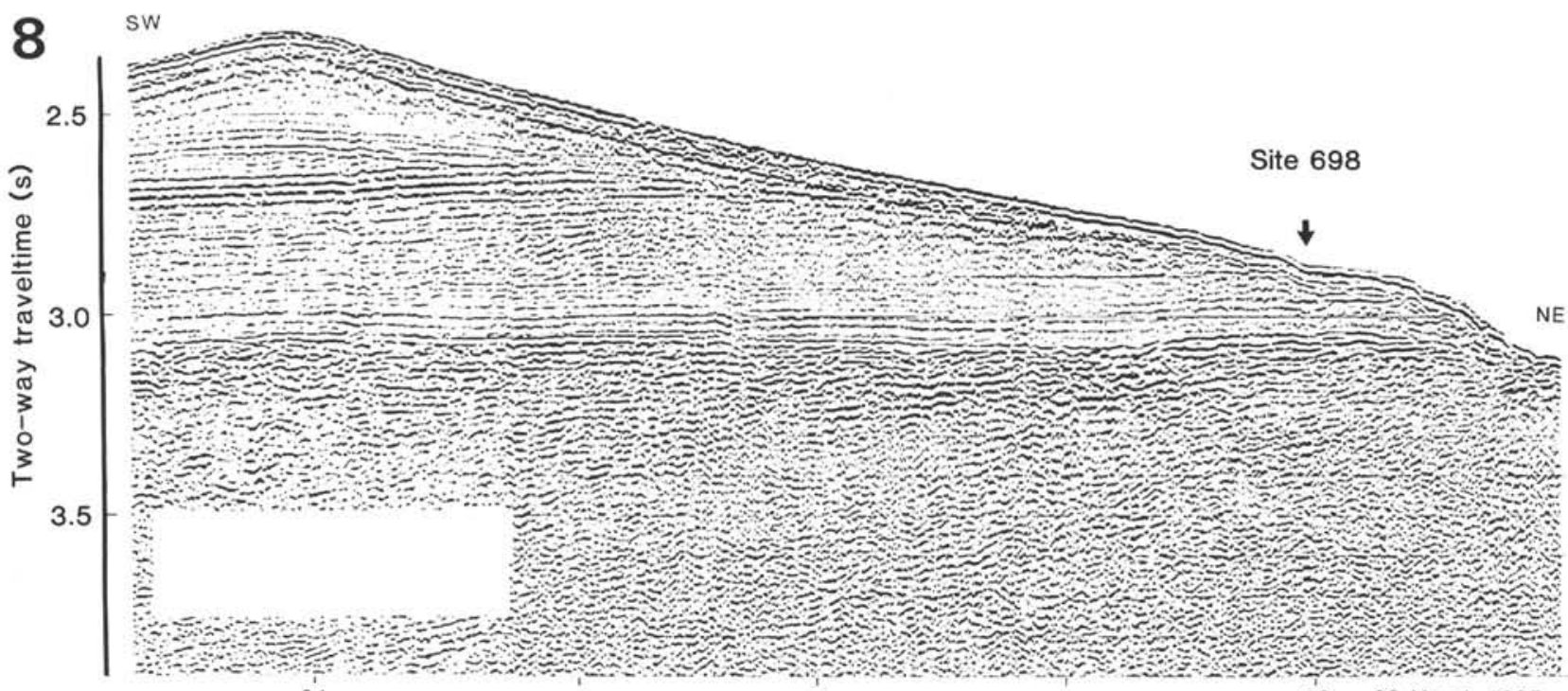

04

03

0220 March 1987

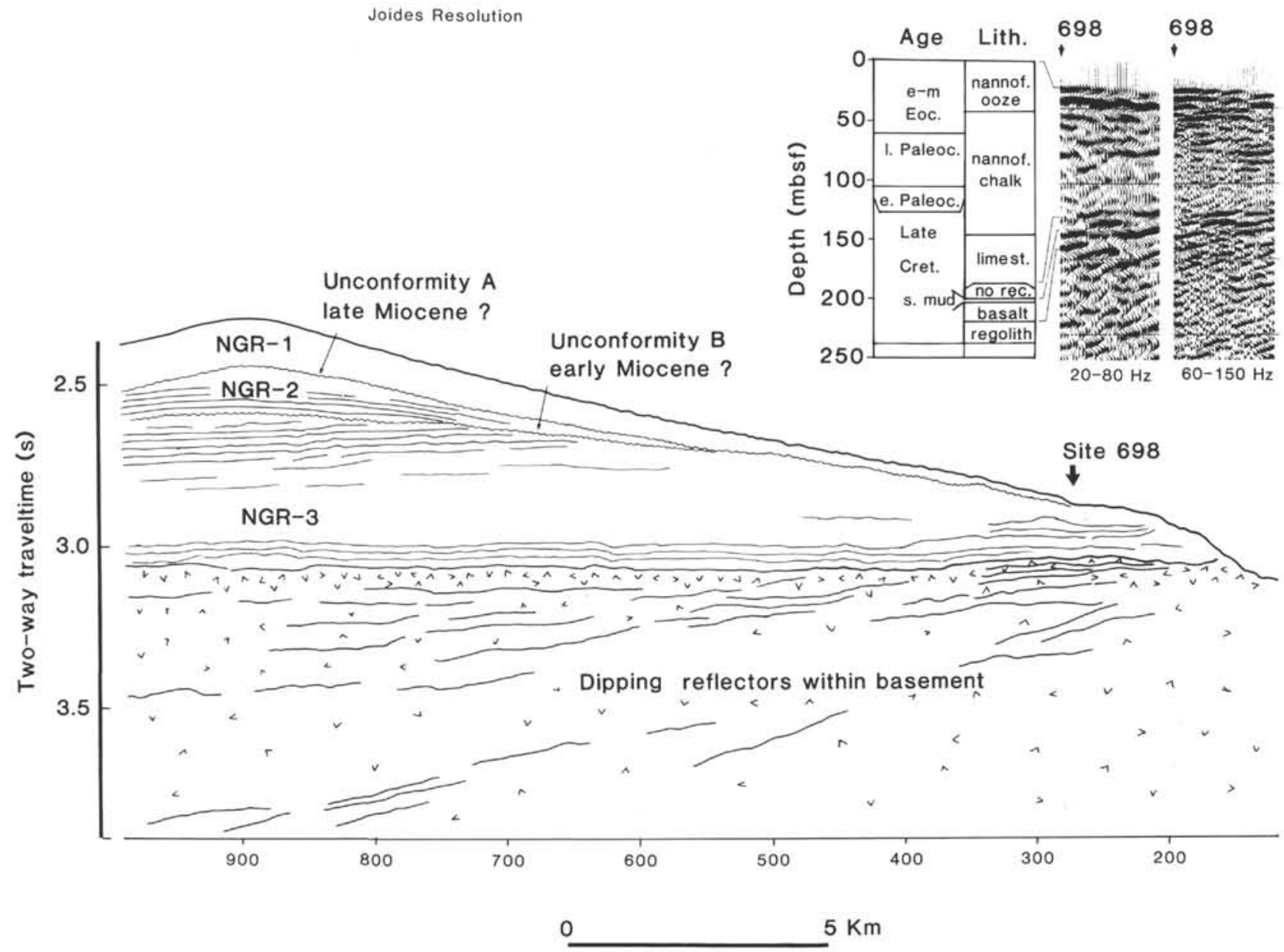

Figure 4. JOIDES Resolution single-channel seismic profile recorded through Site 698 across the crest of the western ridge of the Northeast Georgia Rise and a line drawing of interpreted unconformities A and B and seismic sequences NGR-1-NGR-3. Profile location 8 is shown in Figure 1. Drilling at Site 698 recovered early middle Eocene nannofossil ooze passing into chalk and limestone of Late Cretaceous (Campanian) age and $10 \mathrm{~m}$ of basalt and $17 \mathrm{~m}$ of weathered basalt (regolith) from the bottom of the hole (Ciesielski, Kristoffersen, et al., 1988). 

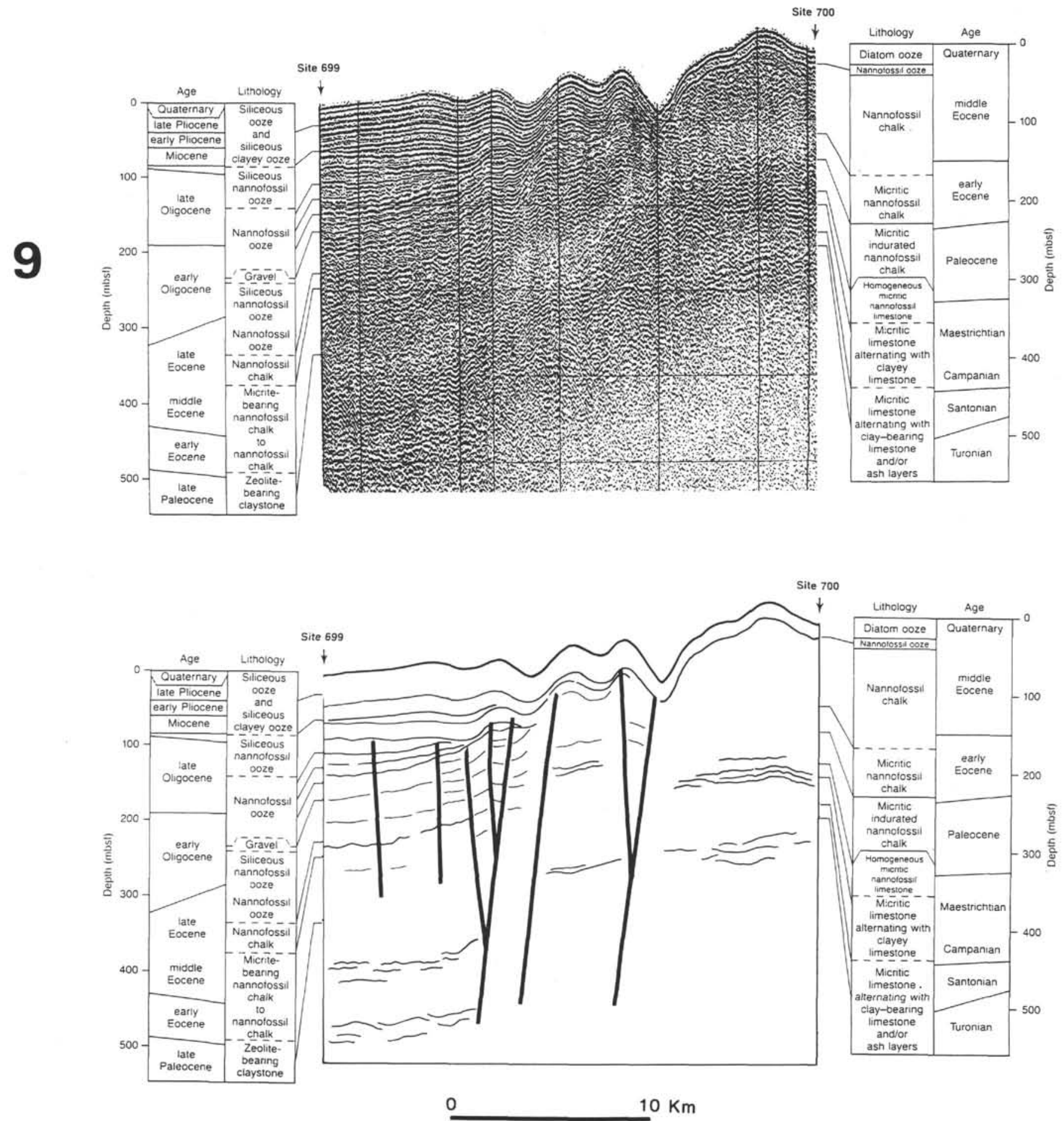

Figure 5. JOIDES Resolution single-channel seismic profile from the eastern part of the Northeast Georgia Rise between Sites 699 and 700 . Profile location 9 is shown in Figure 1. Lithostratigraphy and ages after Ciesielski, Kristoffersen, et al. (1988).

crest of the western ridge and thins toward the edge of the ridge (Fig. 4). Sequence NGR-2 reaches a maximum thickness of $360 \mathrm{~m}$ (assuming a velocity of $1700 \mathrm{~m} / \mathrm{s}$ ) and is acoustically semitransparent in its upper part and well stratified in its lower part. The sequence displays indications of differential thinning or thickening toward the ridge perimeter or basement highs. The underlying sequence NGR-3 reaches a maximum thickness of $650 \mathrm{~m}$ (assuming a velocity of $2000 \mathrm{~m} / \mathrm{s}$ ) at the crest of the ridge. West and south of Site 698 , the sequence is characterized by a band of low-frequency reflections $(50 \mathrm{~m}$ thick) above acoustic basement in its lower part, a semitransparent middle part, and a band of low-frequency events in its upper part. The internal reflections within the basal part of this sequence indicate differential thickening to the west, whereas a distinct feature for the remainder of this sequence is the apparent lack of change in thickness of internal reflection 
packages toward the ridge perimeter prior to being cut by the unconformity at or near the seafloor. The deposits on the southwestern part of the Northeast Georgia Rise are heavily deformed, but we can tentatively identify remanents of a sequence with general reflection characteristics resembling those described for the upper sequences (NGR-1-NGR-2) deposited on the high-standing western ridge farther north. The best example is preserved in a unit that we interpret as a gravity slide (Figs. 6 and 7). We will detail the evidence for this sediment body as a separate structural unit in the following discussion on the tectonic history of the Northeast Georgia Rise.

ODP Leg 114 drilling at Site 698 penetrated the lower part of sequence NGR-3 (Fig. 4). Upper Cretaceous (CampanianMaestrichtian) basal limestone containing numerous chert stringers is associated with the low-frequency acoustic stratification (Ciesielski, Kristoffersen, et al., 1988). The overlying Paleocene-upper Eocene chalk is largely acoustically transparent at this site as well at Sites 699 and 700 .
Drilling results from Site 698 are inconclusive as to the age of unconformity A. An estimated maximum thickness of $4 \mathrm{~m}$ of Pliocene(?) sediments overlies middle Eocene nannofossil ooze with a gravel lag deposit of ice-rafted detritus at the seafloor (Ciesielski, Kristoffersen, et al., 1988). The seismicreflection characteristics of the sequences above unconformity $\mathbf{B}$ on the western ridge appear broadly similar to those of the Oligocene and younger sediments at Site 699. Although the environments and depths differ between these two areas, we have no other recourse at this stage than to try the sedimentation rate of $12 \mathrm{~m} / \mathrm{m}$.y. from Site 699 for the last 2.5 m.y. (Ciesielski, Kristoffersen, et al., 1988) in an attempt to estimate the time required to deposit the total $130-\mathrm{m}$ thickness of sequence NGR-1 on the western ridge. This gives an age of about $11 \mathrm{Ma}$ for the stratigraphic level of unconformity A. Similarly, we may use the average sedimentation rate (15 $\mathrm{m} / \mathrm{m}$.y.) of the Eocene to Oligocene sequences at Site 699 (Ciesielski, Kristoffersen, et al., 1988) to estimate the age of the interpreted correlative conformable stratigraphic level of
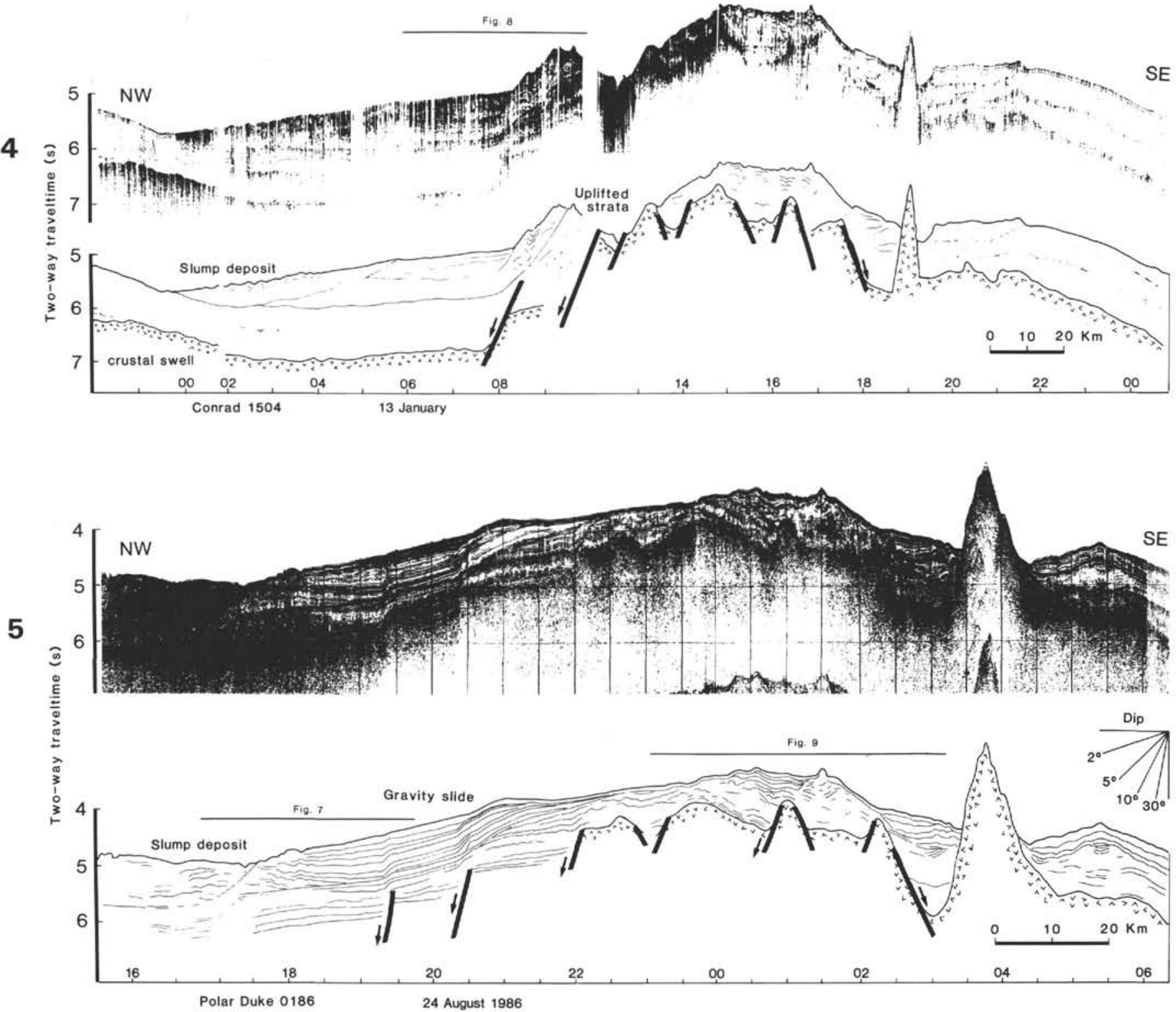

Figure 6. Single-channel seismic-reflection profiles and corresponding line drawings with interpreted basement faults and sediment cover units. Profile locations 4 and 5 are shown in Figure 1. 
unconformity B (profile 2, 0700-0730 hr; Fig. 3) at about 20 Ma. Consequently, the significance of these inferred ages is necessarily rather questionable at this point. We note that the entire Oligocene through Miocene and part of the Pliocene(?) section is missing at the sites drilled on topographic highs on the rise (Sites 698 and 700; Fig. 2). The sedimentary record at Site 699 , however, is continous through the Oligocene into the early Miocene. After a break, lower upper Miocene sediments are present, but the later record is fragmented (Ciesielski, Kristoffersen, et al., 1988). Although the western ridge is a topographic high, the maximum sediment thickness above unconformity B is nearly $500 \mathrm{~m}$ and the assumed age requires high accumulation rates and/or nearly continous deposition during the Neogene in this area. The lithology of the sediments deposited on the western ridge above unconformity $\mathrm{B}$ is expected to be similar to the corresponding Oligocene and younger sequence of Site 699.

The thickness of the sediments deposited on the lesser eastern ridge of Northeast Georgia Rise is about $800 \mathrm{~ms}$ two-way traveltime (twt) where undisturbed (Figs. 2 and 5). Fault movements have exposed some blocks to erosion, resulting in an uneven total sediment thickness. The acoustic image of the sediments is characterized by an upper stratified acoustic unit, more than $400 \mathrm{~ms}$ (twt) thick, overlying a more transparent, weakly bedded 300 -ms-thick interval. A band $(80$ ms twt) of low-frequency reflections forms the lowermost unit over basement with no distinct acoustic expression of the sediment/basement contact below (Ciesielski, Kristoffersen, et al., 1988). The sparse coverage and quality of the seismic data over this part of the rise area do not justify any detailed seismic sequence analysis except in the vicinity of the drill sites (Fig. 5). In general terms, the drilling results from Sites 699 and 700 show that the acoustically stratified unit correlates with the part of the section that consists of nannofossil and siliceous oozes (middle Eocene and younger) and the uppermost chalk unit, whereas the transparent acoustic signature correlates with chalk and limestone (Ciesielski, Kristoffersen, et al., 1988). The basal acoustic unit was not penetrated by drilling, but upper Turonian limestone (Premoli Silva, this volume) with clay and/or ash layers at about $100 \mathrm{~m}$ above basement at Site 700 is the oldest rock encountered on the Northeast Georgia Rise.

\section{Sediments in the Deep Western Georgia Basin}

The deposits in the deep basins adjoining the Northeast Georgia Rise are tectonically undisturbed and have a thickness of 1-2 s twt, with the maximum thickness exceeding 2.5 $s$ toward the west (Figs. 1 and 10). The lower part of the section $(0.5-1.0 \mathrm{~s}$ twt) is characterized everywhere by acoustically transparent sediments, whereas the upper part has multiple internal reflections and increases in thickness toward the west. East and south of the Northeast Georgia Rise, a distinct reflection event is developed in the middle part of the section (Fig. 6).

The sediments in the deep basin were sampled at Deep Sea Drilling Project (DSDP) Site 328 (Fig. 10). Here, an upper 50 -m-thick acoustically reflective unit of siliceous ooze and clay (Oligocene and younger) overlies acoustically transparent zeolitic clay and claystone down to $300 \mathrm{~m}$ below seafloor (mbsf) and variegated clay to total depth of 488 mbsf (Barker, Dalziel, et al., 1977). The oldest recovered sediments are considered to be late Turonian-Cenomanian. A diffuse reflector interpreted to relate to secondary diagenesis in a uniform sequence of siliceous clay and claystone within the Upper Cretaceous sediments forms a diachronous horizon (Zimmerman et al., 1979). A corresponding diffuse reflection band can be tied to the western Georgia Basin (profile 7; Fig. 10).
There is a dramatic difference between the deposits on the Northeast Georgia Rise and the surrounding basins in the amount of clay in the sediments (Ciesielski, Kristoffersen, et al., 1988). Clay-rich sediments were deposited throughout the entire Georgia Basin during the Late Cretaceous (Barker, Dalziel, et al., 1977). The basins were below the carbonate compensation depth (CCD), whereas Site 700 situated above the CCD received clay-bearing carbonate sedimentation and the shallower Site 698 received no clay. At the close of the Eocene there was a major decrease in the amount of clay and an increase in biosiliceous material supplied to the basin. Shallower sites show a reduction in clay content received during the late Eocene-early Oligocene, followed by an increase during the late Oligocene.

\section{TECTONIC HISTORY}

The varying displacement of the different stratigraphic markers and increasing disturbance of the sediments, particularly south of $52^{\circ} \mathrm{S}$, indicate that the Northeast Georgia Rise underwent tectonic deformation after its formation (Figs. 1, 3, and 6).

Vertical movements along the western flank of the Northeast Georgia Rise can be recognized by the upbending of strata in the adjacent basin floor with no apparent thickening of individual beds toward the foot of the basement scarp (Figs. 1 and 8 ). The uplift starts at about $51^{\circ} 30^{\prime} \mathrm{S}$, increases southward, and is estimated to be about $750 \mathrm{~m}$ at $52^{\circ} 15^{\prime} \mathrm{S}, 34^{\circ} \mathrm{W}$, and about $1 \mathrm{~km}$ at $53^{\circ} \mathrm{S}$ from the present position of depositional interfaces in relation to an assumed initially flat depositional surface on the basin floor.

At $53^{\circ} \mathrm{S}$, the western ridge flank is covered by a 0.75 -s-thick acoustically well-stratified unit that overlies the deeper strata with a distinct unconformity (Figs. 6 and 7). Strata within the unit undulate at the basinward end whereas acoustic horizons below the unconformity appear to be flat. At its shallower eastern end, the acoustic layering appears to onlap eastward against an internal unconformity. Unfortunately, no other seismic-reflection data are available to further delineate this acoustic unit. Truncation of strata, apparent onlap, and undulating bedforms may be primary erosional and depositional features, but may alternatively represent detachments and associated internal deformation. These things considered, we favor an interpretation in which the undulating internal acoustic horizons toward the basin represent internal deformation within the reflective unit, which in turn implies downslope movement as a gravity slide driven by its potential energy derived from the uplift of the underlying basement.

The reflective unit terminates against a zone of partly chaotic reflections involving the upper $0.9 \mathrm{~s}$ of the sediments. The zone is confined to the bathymetric low at the junction between the Northeast Georgia Rise and the South Georgia block (Figs. 1, 6, and 7). Hummocky seafloor and underlying chaotic reflections are also observed $50 \mathrm{~km}$ farther downslope to the north (profile 4; Fig. 6), and the toe may extend to $52^{\circ} \mathrm{S}$ (Fig. 1). We interpret this reflection signature to represent massive slump deposits derived either from the southwesternmost part of the Northeast Georgia Rise or the adjacent margin of South Georgia.

The sediment cover on the crest of the southwestern extension of the Northeast Georgia Rise consists of laterally restricted packages commonly with wavy internal acoustic stratification (Figs. 6 and 9), and we note that the deepest part of the section is piecewise conformable with the basement. The present slope of the deeper depositional surfaces is about $3^{\circ}$, which may have rotated from an initial shallower slope. The lateral variations in geometry and angular relationships of the youngest sediments suggest strong bottom current control 

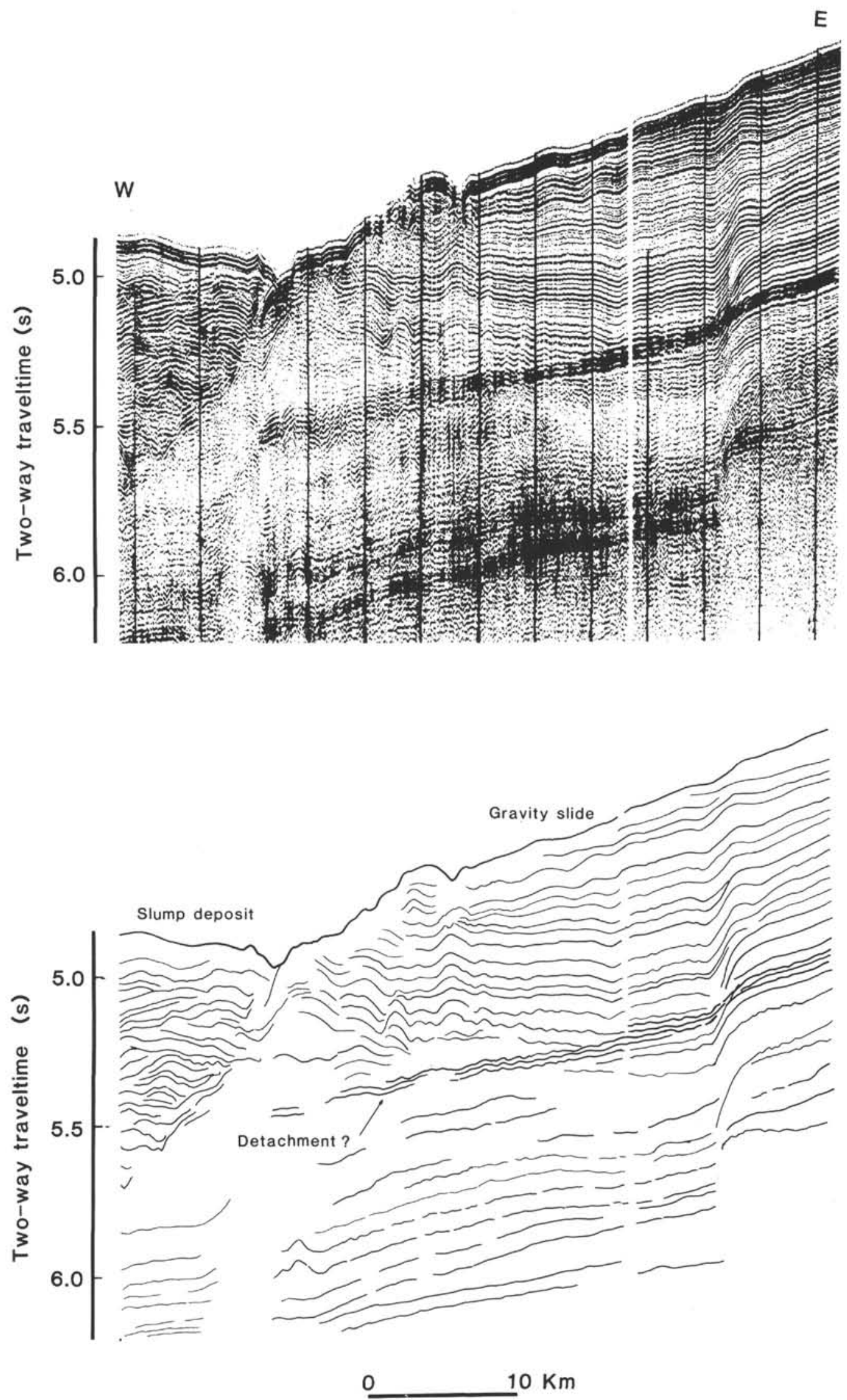

Figure 7. Segment of the Polar Duke single-channel seismic-reflection profile across the lower southwestern flank of the Northeast Georgia Rise and corresponding line drawing. Location of segment from profile 5 is shown on profile 4 in Figure 6 . Note the interpreted base of the gravity slide. 
on erosion and deposition and/or exposure to differential erosion by fault movements. Basement in the crest area forms smaller north-trending ridges (profiles 4 and 5; Figs. 1 and 6).

A steplike basement topography and the vertically displaced overlying strata on the high-standing western ridge of the Northeast Georgia Rise allow us to map out major north-trending faults (profiles 1-3; Figs. 1 and 3). Faults on the eastern side of the western ridge are inferred from vertical differences in basement level, as the sediments are strongly attenuated. A 30-km-wide north-trending graben cuts obliquely across the northern part of the western ridge of the Northeast Georgia Rise and forms a basement terrace south of $51^{\circ} 40^{\prime} \mathrm{S}$ (Figs. 1 and 3). A thick section of sediments is preserved on the terrace. The main displacement $(400 \mathrm{~m})$ on the fault bounding the graben to the east is older than unconformity B. Later reactivation is evident as even the youngest sediments on the ridge are involved in a flexure above the fault trace with a vertical displacement of up to 100 m.

Drilling at Site 698 sampled a 200 -m-thick section of Late Cretaceous to middle Eocene carbonates overlying highstanding basement. The depth information derived from benthic foraminiferal assemblages at the site suggests a lower bathyal $(1500 \pm 500 \mathrm{~m})$ setting in the Paleocene (Katz and Miller, this volume). The late Paleocene and early Eocene backtracked depths, however, are about 800 and $900 \mathrm{~m}$, respectively. More specifically, Site 698 is the only site of those examined $(698,699,700$, and 702$)$ by Katz and Miller (this volume) that showed a discrepancy between the faunal estimates and paleodepths. A profile across the western ridge through Site 698 (profile 1; Figs. 3 and 8) shows that the observed uplift to the south of the western ridge flank does not extend to this northern location. Hence, any post-early Eocene uplift of the basement at the drill site must have been accommodated by motion on faults cutting through the ridge and on the bounding faults to the east (Figs. 1 and 3). Where the faults on the western ridge offset sedimentary strata, there is evidence of a long period of fault movement from the progressive attenuation upward of the offset along the fault trace (profiles 1 and 2; Fig. 3). Faulting has involved the inferred early Miocene unconformity, but the late Miocene unconformity seems undisturbed. We have no bounds on a maximum age of faulting in this area.

The entire eastern ridge on the Northeast Georgia Rise is dissected by normal faults into blocks of varying sizes with an assumed northern trend (Figs. 1 and 2). The fault traces do not appear to extend into the basin north and south of Northeast Georgia Rise. The sediment-covered blocks are commonly rotated. Leg 114 drilling at Sites 699 and 700 (Ciesielski, Kristoffersen, et al., 1988) together with a seismic tie-line documents tectonic movements on major normal faults (Fig. 5). The area about $10 \mathrm{~km}$ east of Site 699 experienced fault-generated relative uplift by the late early Oligocene, as the younger deposits onlap older flexured units near the fault. However, the dip regimes between the secondary faults appear very complex and raise the possibility of later fault reactivation in a compressional regime. The occurrence of a 2-m-thick gravel bed displaced into a nannofossil ooze of early Oligocene age (34.6-32.5 Ma) at this site may be a result of contemporary tectonic movements. The variation of physical properties with depth at Site 699 compared with that of Site 700 indicates that an estimated thickness of about $350 \mathrm{~m}$ of sediments was removed from the top of the middle Eocene chalk at Site 700 before deposition resumed at that site in the Miocene (Shipboard Scientific Party, 1988b). This compares with the 355-m-thick section of post-middle Eocene to Quaternary age sediments at Site 699. Any second phase of displacement with reactivation of the normal faults between the two sites and erosion of the sediments on the block where Site 700 is located would probably have occurred near the close of the Miocene to allow for sufficient accumulation of overburden.

The seismic data demonstrate uplift along the western flank of the Northeast Georgia Rise of $0.75-1 \mathrm{~km}$, increasing toward South Georgia (Fig. 8). Similarly, the paleodepth estimates from benthic foraminifers suggest that the northeastern part of the western ridge also was subjected to uplift of nearly the same magnitude. This enhancement of relief of the western ridge must have been accommodated by movement on westdipping normal faults on the western side, but more obscurely by inferred east-dipping normal faults on the eastern side (Figs. 1 and 3). Alternatively, the fault movement on the eastern side may have been along west-dipping reverse faults. In the crest area at $53^{\circ} \mathrm{S}$, the inclination of deep acoustic horizons conformable with basement suggests block rotation between bounding faults (Fig. 9). Moreover, we also feel that the geometry and angular relationships of the overlying sediment packages in this area appear too complex to be simply the result of current-controlled deposition and deformation related to normal faulting; components of reverse faulting/ thrusting may also have been involved.

The crustal uplift of part of the western ridge of the Northeast Georgia Rise appears to have been accommodated by movements along low-angle normal faults. Hence, a local east-west extensional regime must have been imposed on the area, particularly during the Neogene. Elevation of basement blocks may have resulted from the unloading of mass on the footwall of the bounding faults.

\section{TECTONIC EVENTS ON THE NORTHEAST GEORGIA RISE IN RELATION TO THE OPENING OF THE SCOTIA SEA}

The generally undisturbed nature of the sediments in the deep Georgia Basin surrounding the Northeast Georgia Rise gives little reason to relate the Cenozoic tectonic events on the rise to intraplate phenomena of regional significance. On the other hand, the apparent increase in basement uplift and deformation of the sediment cover toward the South Georgia block suggest some form of tectonic interaction between the two features.

The island of South Georgia, located next to the southwestern extension of the Northeast Georgia Rise, is considered to be a microcontinental block containing a diverse suite of rocks representing a calc-alkaline magmatic arc as well as a back-arc basin environment (Tanner, 1982). Some key aspects of the geology of South Georgia have apparent analogues in the geology of South America, such as the correlation of the volcaniclastic turbidites of the Cumberland Bay Formation with the Yahgan Formation of southern Patagonia (Thomson et al., 1982) and the similarity of the magmatic-arc assemblages of South Georgia to those of the Patagonian batholith (Tanner, 1982). Hence, during the Late Cretaceous, South Georgia is considered to have occupied a position more proximal to the Andean Cordillera (Dalziel, 1983).

From the pattern of magnetic lineations in the Scotia Sea we infer that seafloor spreading between Terra del Fuego and the tip of the Antarctic Peninsula was initiated just prior to Chron $\mathrm{C} 10$ (30 Ma) along a north-northeast-trending western Scotia Sea spreading center. Crustal fragments, such as South Georgia and Shag Rocks (Fig. 11), were dispersed along a northeast-trending predominantly strike-slip boundary parallel to the direction of North Scotia Ridge (Barker and Griffiths, 1972; Barker and Hill, 1981). The southern edge of the North Scotia Ridge probably represents a shear zone whereas the 


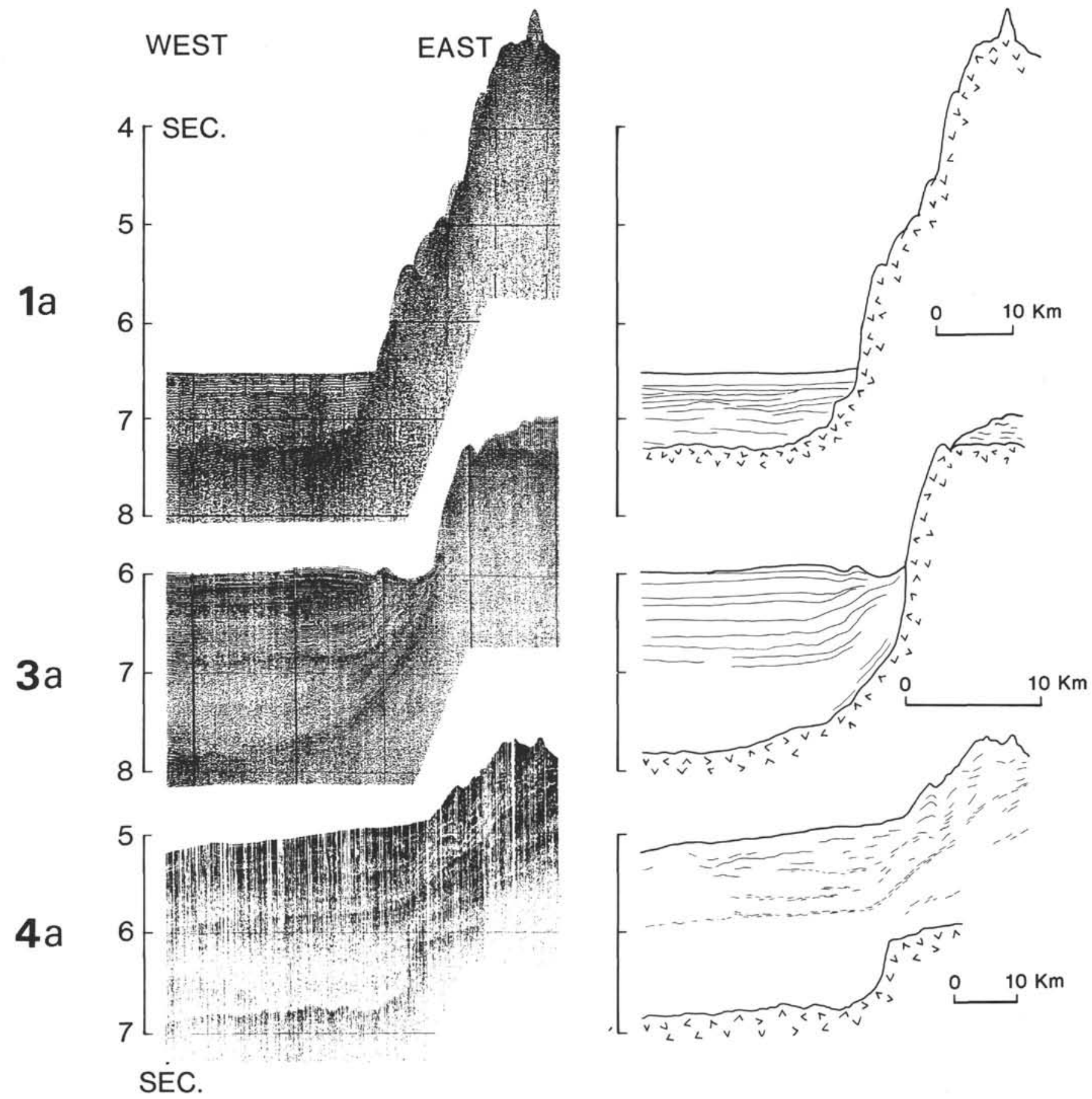

Figure 8. Segments of single-channel seismic profiles across the western flank of the Northeast Georgia Rise with corresponding line drawings demonstrate the increasing uplift of the ridge flank toward the south. Location of segments 1a and 3a shown in Figure 3 and segment $4 \mathrm{a}$ in Figure 6.

northern flank is composed of a thick wedge of deformed sediments (Ludwig et al., 1978). Crustal accretion along the western Scotia spreading center continued until after Chron C5 (late Miocene). A contemporary Miocene east-west spreading axis has been proposed between $35^{\circ}$ and $45^{\circ} \mathrm{W}$ in the Scotia Sea (Hill and Barker, 1980), but the significance of the east-trending magnetic anomalies is debatable. The last phase of back-arc extension began about $8 \mathrm{Ma}$ ago along the northsouth axis of the South Sandwich spreading center south of
South Georgia and resulted in the isolation of South Georgia in its present position (Barker, 1972).

A pertinent question is thus: what was the response of the Cretaceous lithosphere north of South Georgia to the Miocene advance of the trench and the microcontinent? Oceanic crust in the deep basin north of the South Georgia block forms a large swell (the Northwest Georgia Rise) with an excess basement elevation of $4 \mathrm{~s}$ (twt). The swell extends north of $51^{\circ} \mathrm{S}$ (Figs. 1 and 10). The uplifted crust does not appear 

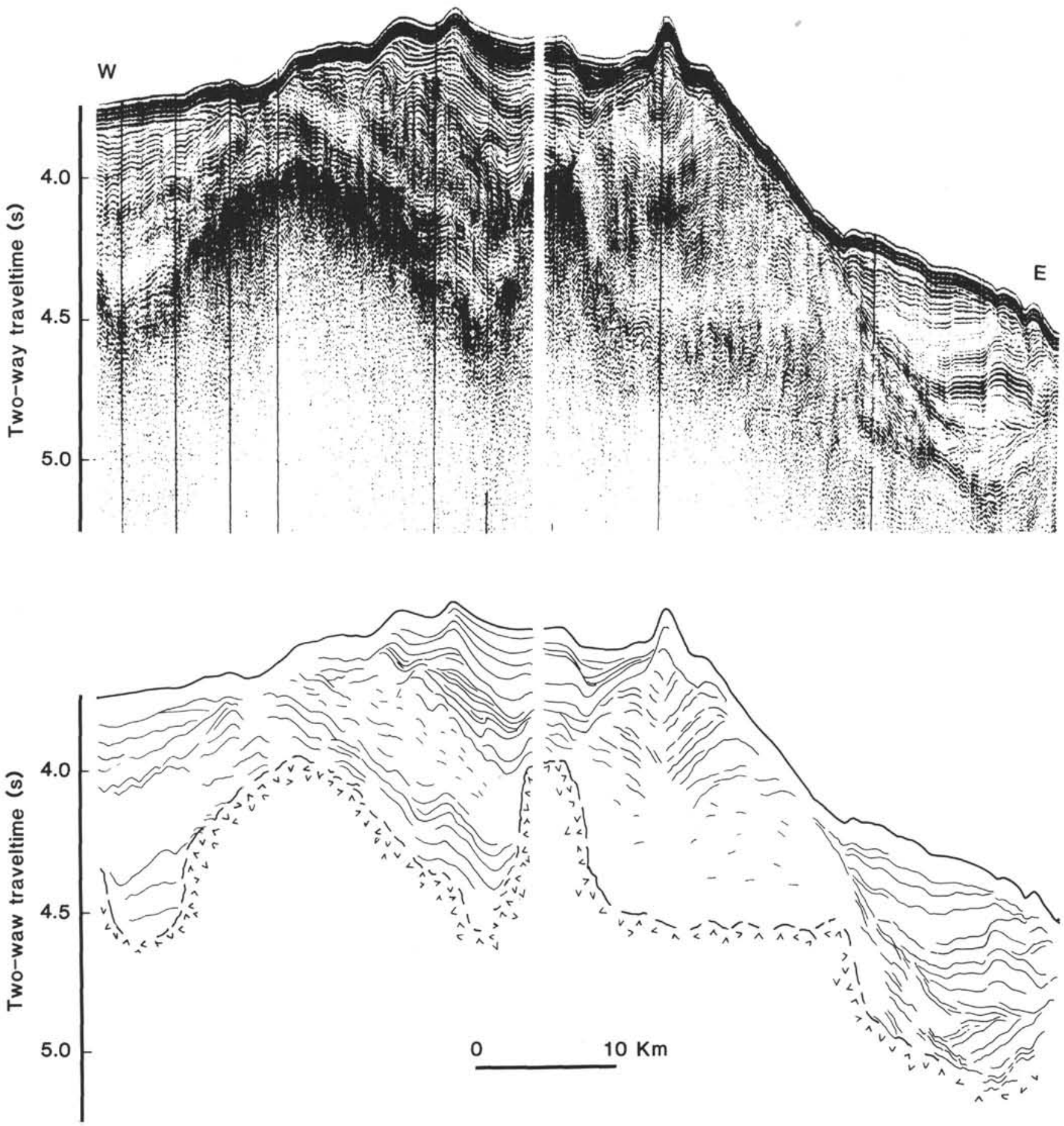

Figure 9. Segment of the Polar Duke single-channel seismic-reflection profile across the crest of the southwestern part of the Northeast Georgia Rise with corresponding line drawing demonstrates structural details of the sediment cover on basement blocks. Location of segment of profile 5 shown in Figure 6.

severely disrupted. The acoustically transparent basin sediments characteristic of the pre-Late Cretaceous-early Cenozoic age section are involved in the uplift whereas younger stratified sediments of possible post-Eocene age onlap the swell topography from the west (profile 6; Fig. 10). Hence, this feature may have been generated during the early opening of the Scotia Sea. If it was formed later, during the middle to late Miocene, it follows that the onlapping section of acousti- cally well-stratified sediments nearly $1 \mathrm{~s}$ (twt) thick is very young-post-middle Miocene. The cause of the uplift is unknown and we are not aware of comparable lithospheric flexures associated with other arc trench settings.

The increasing intensity of deformation of the sediment cover on the Northeast Georgia Rise toward South Georgia may relate to Neogene tectonic interaction of the microcontinent with the rise or result from the lithospheric response to 
6
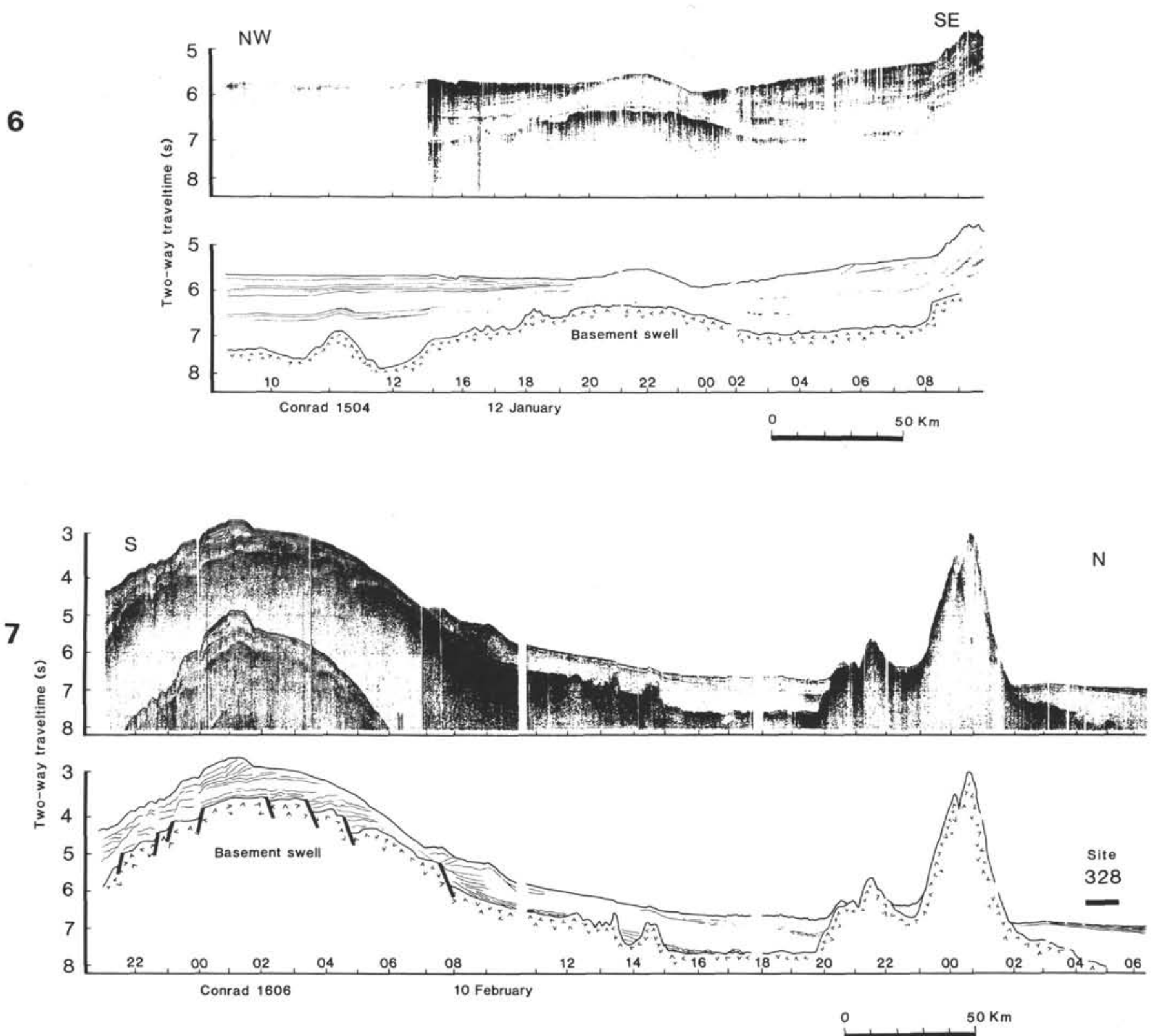

Figure 10. Single-channel seismic-reflection profiles across the basement swell in the Georgia Basin with corresponding line drawings. Profile locations 6 and 7 are shown in Figure 1.

the advancing South Sandwich Trench. The attitude and structural styles of the deformed basement cover on the southwestern part of Northeast Georgia Rise suggest that crustal extension took place with the uplift of crustal blocks of the order of $0.5-1 \mathrm{~km}$ along low-angle normal faults. An extensional regime may have developed as the anomalous basement elevation represented by Northeast Georgia Rise came into the forebulge region of the eastward-advancing trench during the late Miocene (Fig. 11). Alternatively, we may speculate that possible subduction of unknown basement topography south of the Northeast Georgia Rise may have set up contributing deviatoric extensional stresses. An older (Oligocene?) east-west extensional phase that affected the Northeast Georgia Rise may relate to tectonic events associated with the initial opening of the Scotia Sea. There are also some indications of the subsequent reactivation of normal faults in a compressional regime.

\section{HOW WAS NORTHEAST GEORGIA RISE FORMED?}

The difference in lithology between the clay-rich Georgia Basin sediments (Site 328) and the basal carbonate section recovered from the sites on the Northeast Georgia Rise clearly demonstrates that an elevated rise was present during Turonian time. Sites 328, 700, and 698 occupied successively shallower depths with respect to the Late Cretaceous CCD as evidenced by the carbonate content of the sites. This is also true of the present-day relief of the Georgia Basin.

We have considered several possible modes of origin for the Northeast Georgia Rise, ranked by age of formation:

1. Continental fragment.

2. Oceanic plateau formed by excess volcanism at a spreading center. 

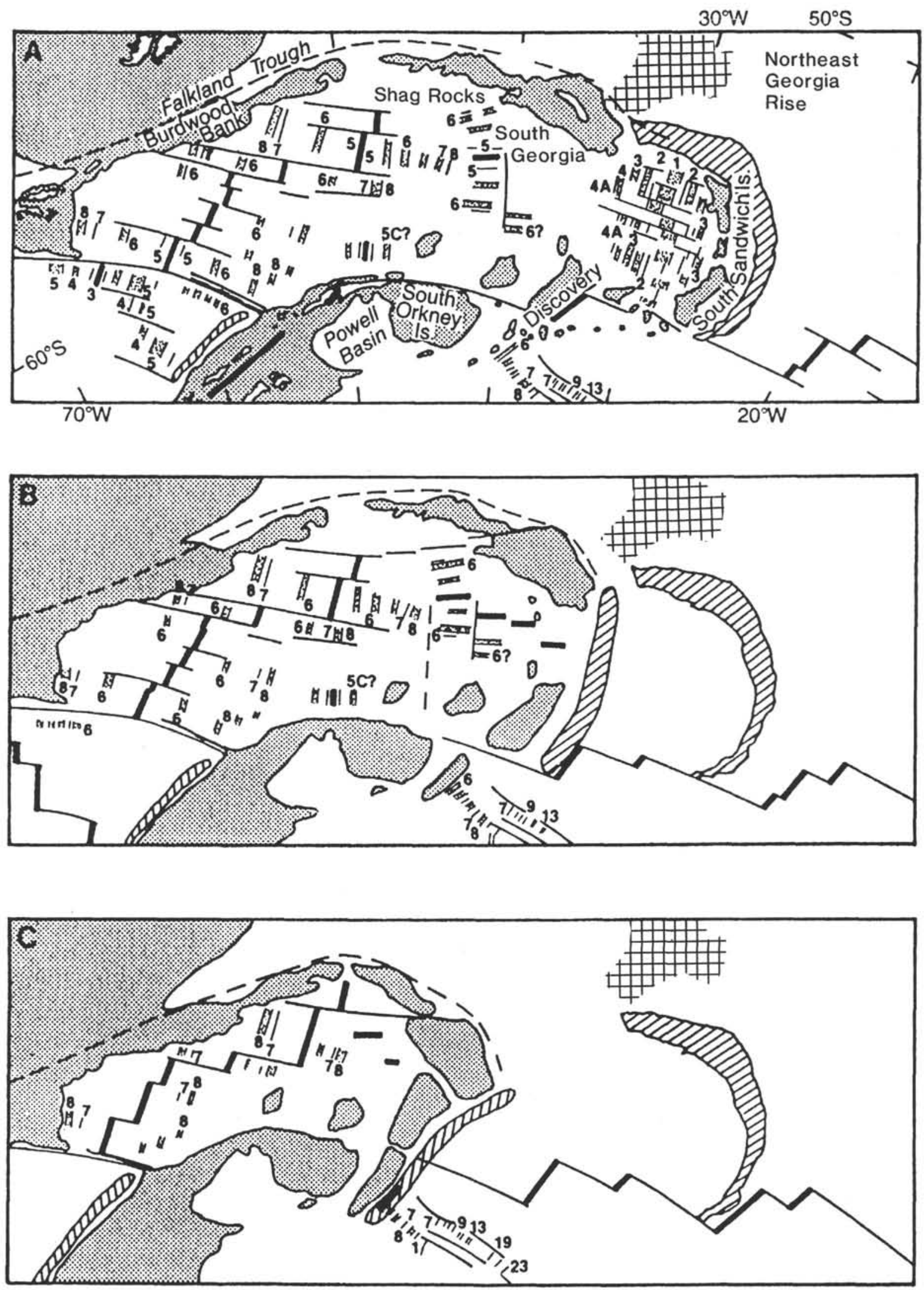

Figure 11. A model of the tectonic evolution of the Scotia Sea region over the past $20 \mathrm{Ma}$ in relation to the position of the Northeast Georgia Rise (after Barker et al., 1984). Shaded regions represent shallow areas (continental and island arc above the $2000-\mathrm{m}$ isobath). The crosshatched area shows the position of Northeast Georgia Rise, as outlined by the $4000-\mathrm{m}$ isobath. The hachured present-day position of the South Sandwich Trench illustrates back-arc extensional development. A. Present-day tectonic setting. B. Anomaly $5(10 \mathrm{Ma})$ reconstruction. C. Anomaly $6(20 \mathrm{Ma})$ reconstruction. 


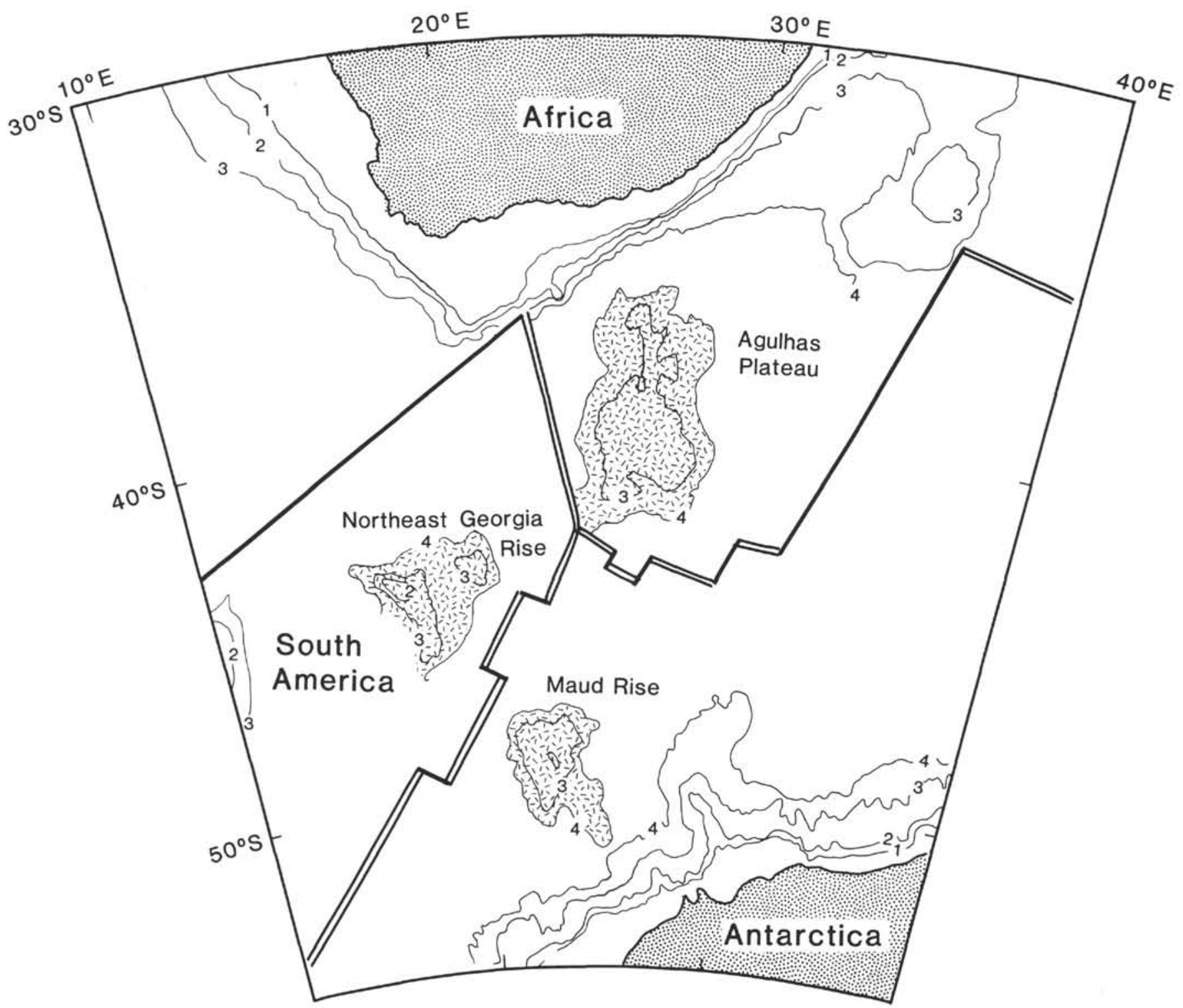

Figure 12. Reconstruction of the relative positions of Africa, South America, and Antarctica in the frame of Africa at $90 \mathrm{Ma}$. The total rotation was extrapolated from the fit at Chrons C34 (Cande et al., 1988; Royer et al., in press) and CM0 (Rabinowitz and LaBrecque, 1979; Norton and Sclater, 1979). The stippled areas of the Agulhas Plateau and the Northeast Georgia and Maud rises are outlined by the present-day 4000 -m isobath. The estimated positions of the spreading ridges and fracture zones are shown by double and single heavy lines, respectively.

3. Oceanic plateau formed by off-axis volcanism.

4. Embryonic island arc.

\section{Continental Fragment}

The Georgia Basin is assumed to be floored by oceanic crust that formed during the relative motion between South America and Africa (Fig. 1). To include a continental fragment in the structural framework of the Northeast Georgia Rise requires one or more jumps in the position of the spreading center, as invoked by Tucholke et al. (1981) and Martin and Hartnady (1986) to explain the proposed continental nature of part of the Agulhas Plateau surrounded by oceanic crust. We can, at this point, find no convincing geophysical evidence for a pre-Maestrichtian shift in the position of the spreading center or the presence of major fracture zones within the Georgia Basin. The provenance and possible significance of the gravel bed observed at Site 699 therefore remain enigmatic at this point.

\section{Formed at a Spreading Center}

Figure 12 displays a reconstruction of the Indo-Atlantic region for Turonian time ( $90 \mathrm{Ma})$, which is the time of deposition of the oldest sediments recovered by Leg 114 drilling on the Northeast Georgia Rise. The location of the Africa-South America spreading center was determined by interpolation between the magnetic anomaly 34 lineation of the Agulhas Magnetic Bight (Bergh and Barrett, 1980) and the M sequences in the Natal Valley (Goodlad et al., 1982) and Georgia Basin (LaBrecque and Hayes, 1979). The AfricaAntarctica and the Antarctica-South America spreading-center locations are constrained by a combination of the anomaly 34 lineations (Royer et al., in press) and a Geosat-derived gravity field (Haxby, 1988).

The Northeast Georgia Rise, Agulhas Plateau, and Maud Rise may share some common evolutionary aspects. The estimated age of basement at Site 700 is Albian (100 Ma), 
which agrees with the predicted age of basement from magnetic isochrons (Fig. 1). The minimum age of the Agulhas Plateau given by Cenomanian sediment samples recovered from its western and northern flanks (Tucholke and Carpenter, 1977) is also consistent with the isochron rotations. Two other considerations also support the hypothesis that the Agulhas Plateau was formed at a spreading center. First, we find no evidence for major jumps of the South America-Africa spreading center prior to anomaly 34 except for the elimination of a small offset in anomaly M0 (Fig. 1). Second, the basement structure of the Agulhas Plateau appears consistent with the generation of a rise by high volcanic effusion at a spreading center, as we interpret the smooth basement structure with internal reflections (Tucholke and Carpenter, 1977) to indicate the presence of a thick pile of volcanic flows that was probably extruded under subaerial or shallow-marine conditions. Another observation is that the southwestern spur of the plateau extends into the apex of the Agulhas Magnetic Bight and may represent its volcanic trace. However, it is evident from Figure 12 that there are major asymmetries in morphology between the Northeast Georgia Rise and the Agulhas Plateau. The available information does not reveal any major discrepancy between the age of basement as determined from the oldest sediments sampled and the estimated isochrons of the oceanic crust. Therefore, we tentatively conclude that the Northeast Georgia Rise and the Agulhas Plateau formed at the same spreading center, but their subsequent volcanic histories are different.

Drilling at the western Northeast Georgia Rise at Site 698 (Ciesielski, Kristoffersen, et al., 1988) and the Maud Rise at Site 690 (Barker, Kennett, et al., 1988) determined basement to be of Campanian or pre-Campanian age, based on the oldest sediments sampled. This age is much younger than the assumed age of the oceanic crust upon which they are located. Each also displays volcanic cones and sub-basement reflectors. The position of these rises during the Turonian (Fig. 12) reveals a relative proximity suggesting that they may at least in part share a common evolution, although it appears from the Geosat-derived gravity field and anomaly 34 lineations of the intervening seafloor that they were on conjugate ridge flanks during this period of constructional volcanism.

\section{Formed by Off-Axis Volcanism}

The presence of sub-basement acoustic reflections dipping westward from the location of Site 698 is interpreted to indicate still younger volcanism on the western part of the ridge. The age of the oldest fossil-bearing sediments recovered at Site 698 is Campanian (Shipboard Scientific Party, 1988a). We estimate the position of the Turonian plate boundary in the Georgia Basin to be $300 \mathrm{~km}$ east of the Northeast Georgia Rise (Fig. 12). Thus, unless the rise is considerably older than the oldest sediments recovered by Leg 114 drilling, off-axis volcanic activity did indeed take place. Preliminary geochemical analysis of basalt samples from Site 698 shows that some samples are transitional, but most are moderately evolved alkalic basalts and hawaiites-chemically like samples from numerous intraplate hot spots (M. Perfit, pers. comm., 1988). Construction of at least part of the western ridge of the Northeast Georgia Rise may therefore be due to intraplate hot-spot activity.

\section{Embryonic Island Arc}

The only published proposal to date for the origin of the Northeast Georgia Rise is one that considers the rise to be a tectono-magmatic feature related to interaction between a Malvinas microplate and South America during the Late Cretaceous-early Paleocene (LaBrecque, 1986; LaBrecque and Hayes, 1979). Testing of this proposal formed part of the tectonic objectives for Leg 114 drilling on Northeast Georgia Rise (Ciesielski, Kristoffersen, et al., 1988). The concept of a Malvinas plate was proposed as an explanation for the divergence between the conjugate magnetic lineation directions of anomalies 33 and 34 in the Agulhas Basin. This pattern deviates significantly from the South Atlantic pattern of opening. At the Agulhas Triple Junction, the Malvinas plate formed a common boundary with the African and Antarctic plates during the Late Cretaceous until the earliest Paleocene, when a $825-\mathrm{km}$ westward jump in the spreading center welded parts of the Malvinas plate to the South American, African, and Antarctic plates. It was suggested that convergence predicted by the poles of rotation for Malvinas-South America was responsible for the midplate volcanism with incipient subduction that formed the Northeast Georgia Rise during the Late Cretaceous.

After volcanism ended at Site 698 it continued for an unknown period of time farther west and built up the western rim of the Northeast Georgia Rise. The complete lack of volcanic constituents in the oldest carbonate sediments recovered at this site strongly suggests that volcanism had ceased on the western ridge by the Campanian. Ash-bearing zeolite clay horizons are present in the Coniacian to upper Santonian limestone at Site 700 and scattered traces of ash are also present in the upper Maestrichtian-lower Paleocene section (Shipboard Scientific Party, 1988a). Thus, there may be limited overlap in time between the life span of the Malvinas plate and volcanism on the Northeast Georgia Rise. More importantly, however, the Upper Cretaceous sediments recovered at Sites 698 and 700 document carbonate deposition in a quiet environment with only minor traces of volcanic material. Hence, the drilling results do not directly support the idea of an embryonic island arc formed during the Late Cretaceous, but do not exclude it either.

\section{CONCLUSIONS}

The results of ODP Leg 114 drilling show that the Northeast Georgia Rise is a volcanic constructional feature and that the volcanism is youngest in the west. The lithology of the oldest sediments recovered indicates that basement at these localities represented an elevated region by the Turonian. The age of basement at Site 700 is comparable to the predicted age of the oceanic crust at this locality whereas volcanism at Site 698 is more than $20 \mathrm{~m}$.y. younger than the predicted age of the crust there (Fig. 1). This indicates that part of the Northeast Georgia Rise evolved at a spreading center, but later off-axis volcanism contributed substantial volumes of basalt to build up the western part of the rise. Geochemically the lavas at Site 698 are moderately evolved alkali basalts and hawaiites characteristic of hot-spot activity.

Following its Late Cretaceous formation, the Northeast Georgia Rise experienced at least two episodes of deformation; normal faulting in an extensional regime about early Oligocene time and major block faulting with uplift of parts of the western ridge during the Miocene, most probably the middle to late Miocene. An early Oligocene extensional regime is within the same time frame as the interaction between Antarctica and the South American plate, which led to the opening of the Scotia Sea (Barker and Burrell, 1977). However, the nature and position of the plate boundary extending east from the proto-Scotia Sea are unknown. Faulting dissected a rise that is inferred to have been initially smoother than at present except for the excess topography constructed by late-stage volcanism in its western part. There are some indications of possible later reactivation of the normal faults in a compressional regime. The main Miocene 
event was also extensional and involved the entire Northeast Georgia Rise; the western ridge was most severely affected and experienced uplift of the order of $0.5-1 \mathrm{~km}$, increasing to the south.

The probability of tectonic interaction between the advancing South Sandwich Trench and/or relative motion between the South Georgia block and the Northeast Georgia Rise is evident from the increasing tectonic deformation toward the south on the western ridge of Northeast Georgia Rise. Movements appear to have occurred predominantly on low-angle normal faults in an extensional regime, but the structural relationships become more complex toward the south. A local extensional regime may have been generated as the Northeast Georgia Rise came into the forebulge region of the advancing South Sandwich Trench during the late Miocene. Alternatively, stresses may have been transmitted by a basement structure initially extending farther southwest, but now partly subducted or accreted to the northeast face of the South Georgia block.

\section{ACKNOWLEDGMENTS}

This work was supported by NSF Division of Polar Programs contract DPP8517635 and NSF ODP contract OCE8507681 to John LaBrecque. Yngve Kristoffersen acknowledges support from the Norwegian Research Council for Science and the Humanities. We are grateful to T. Moore, I. Dalziel, and P. Ciesielski for critical reviews, which substantially improved the paper.

\section{REFERENCES}

Barker, P. F., 1972. Magnetic lineations in the Scotia Sea. In Aide, R. J. (Ed.), Antarctic Geology and Geophysics: Oslo (Universitetsforlaget), 17-26.

Barker, P. F., Barber, P. L., and King, E. C., 1984. An early Miocene ridge crest-trench collision on the South Scotia Ridge near $36^{\circ} \mathrm{W}$. Tectonophysics, 102:315-332.

Barker, P. F., and Burrell, J., 1977. The opening of the Drake Passage. Mar. Geol., 25:15-34.

Barker, P. F., Dalziel, I.W.D., et al., 1977. Init. Repts. DSDP, 36; Washington (U.S. Govt. Printing Office).

Barker, P. F., and Griffiths, D. H., 1972. The evolution of the Scotia Ridge and Scotia Sea. Philos. Trans. R. Soc. London A, 271:151183.

Barker, P. F., and Hill, I. A., 1981. Back-arc extension in the Scotia Sea. Philos. Trans R. Soc. London A, 300:249-262.

Barker, P. F., Kennett, J. P., et al., 1988. Proc. ODP, Init. Repts., 113: College Station, TX (Ocean Drilling Program).

Bergh, H. W., and Barrett, D. M., 1980. Agulhas Basin Magnetic Bight. Nature, 287:591-595.

Brenner, C., and LaBrecque, J., 1988. Bathymetry of the Georgia Basin and environs. In Ciesielski, P. F., Kristoffersen, Y., et al., Proc. ODP, Init. Repts., 114: College Station, TX (Ocean Drilling Program), 23-26.

Cande, S. C., LaBrecque, J. L., and Haxby, W. F., 1988. Plate kinematics of the South Atlantic: Chron C34 to present. J. Geophys. Res., 93:13479-13492.

Ciesielski, P. F., and Kristoffersen, Y., et al., 1988. Proc. ODP, Init. Repts., 114: College Station, TX (Ocean Drilling Program).

Dalziel, I.W.D., 1983. The evolution of the Scotia Arc: a review. In Oliver, R. L., James, P. R., and Jago, J. B. (Eds.), Antarctic Earth Science: Cambridge (Cambridge Univ. Press), 283-288.
Eldholm, O., Thiede, J., et al., 1987. Proc. ODP, Init. Repts., 104: College Station, TX (Ocean Drilling Program).

Goodlad, S. W., Martin, A. K., and Hartnady, C.J.H., 1982. Mesozoic magnetic anomalies in the southern Natal Valley. Nature, 295:686-688.

Haxby, W. F., 1988. Organization of oblique sea floor spreading into discrete, uniformly spaced ridge segments: evidence from Geosat altimeter data in the Weddell Sea. EOS, Trans. Am. Geophys. Union, 69:1155. (Abstract)

Hill, I. A., and Barker, P. F., 1980. Evidence for Miocene back-arc spreading in the central Scotia Sea. Geophys. J. R. Astron. Soc., 63:427-440.

Kent, D. V., and Gradstein, F. M., 1985. A Cretaceous and Jurassic geochronology. Geol. Soc. Am. Bull., 96:1419-1427.

LaBrecque, J. L. (Ed.), 1986. South Atlantic Ocean and Adjacent Continental Margin, Atlas 13: Ocean Margin Drilling Program Reg. Atlas Ser., 13.

LaBrecque, J. L., and Hayes, D. E., 1979. Sea floor spreading history of the Agulhas Basin. Earth Planet. Sci. Lett., 45:411-428.

Ludwig, W. J., Windisch, C. C., Houtz, R. E., and Ewing, J. L., 1978. Structure of Falkland Plateau and offshore Tierra del Fuego, Argentina. In Watkins, J. S., Montadert, L., and Dickerson, P. W. (Eds.), Geological and Geophysical Investigations of Continental Margins: AAPG Mem., 29:125-137.

Martin, A. K., and Hartnady, C.J.H., 1986. Plate tectonic development of the southwest Indian Ocean: a revised reconstruction of East Antarctica and Africa. J. Geophys. Res., 91:4767-4786.

Norton, I. O., and Sclater, J. G., 1979. A model for the evolution of the Indian Ocean and the break-up of Gondwanaland. J. Geophys. Res., 84:6803-6830.

Rabinowitz, P. D., and LaBrecque, J. L., 1979. The Mesozoic South Atlantic Ocean and evolution of its continental margins. J. Geophys. Res., 84:5973-6002.

Royer, J. Y., Patriat, P., Bergh, H., and Scotese, C. R., in press. Evolution of the Southwest Indian Ridge from the Late Cretaceous (anomaly 34) to the middle Eocene (anomaly 20). Tectonophysics.

Shipboard Scientific Party, 1988a. Site 698. In Ciesielski, P. F., Kristoffersen, Y., et al., Proc. ODP, Init. Repts., 114: College Station, TX (Ocean Drilling Program), 87-150. 1988b. Site 700. In Ciesielski, P. F., Kristoffersen, Y., et al., Proc. ODP, Init. Repts,, 114: College Station, TX (Ocean Drilling Program), 255-362.

Tanner, P.W.G., 1982. Geologic evolution of South Georgia. In Craddock, C. (Ed.), Antarctic Geoscience: Madison, WI (Univ. Wisconsin Press), 167-178.

Thompson, M.R.A., Tanner, P.W.G., and Rex, D. C., 1982. Fossil and radiometric evidence for ages of deposition and metamorphism of sedimentary sequences on South Georgia. In Craddock, C. (Ed.), Antarctic Geoscience: Madison, WI (Univ. Wisconsin Press), 177-184.

Tucholke, B. E., and Carpenter, G. B., 1977. Sediment distribution and Cenozoic sedimentation patterns on the Agulhas Plateau. Geol. Soc. Am. Bull., 88:1337-1346.

Tucholke, B. E., Houtz, R. E., and Barrett, D. M., 1981. Continental crust beneath the Agulhas Plateau, southwest Indian Ocean. $J$. Geophys. Res., 86:3791-3806.

Zimmerman, H. B., Supko, P. R., and McCoy, F. W., 1979. Acoustic horizons in the Argentine Basin, southwestern Atlantic Ocean: new evidence from deep-sea drilling. Geology, 7:45-48.

Date of initial receipt: 12 June 1989

Date of acceptance: 12 December 1989

Ms 114B-173 